\title{
Penerapan Modul Getaran Gelombang dan Bunyi Bermuatan Karakter untuk Meningkatkan Hasil Belajar Siswa
}

\author{
Wanda Aulia ${ }^{1 \star}$, Mustika Wati ${ }^{2}$, dan Misbah ${ }^{3}$ \\ $1^{\star}, 2,3$ Pendidikan Fisika, FKIP, Universitas Lambung Mangkurat \\ *E-mail Penulis Korespondensi: wandaaulia27@gmail.com
}

\begin{abstract}
Abstrak
Penelitian ini bertujuan untuk mendeskripsikan: keterlaksanaan RPP, hasil belajar siswa dan pencapaian karakter kayuh baimbai. Penelitian ini menggunakan Penelitian Tindakan Kelas. Penelitian ini dilakukan sebanyak dua siklus. Subjek penelitian ini 29 orang siswa kelas VIII di salah satu SMP Negeri di kota Banjarmasin. Data diperoleh melalui observasi, tes hasil belajar dan lembar penilaian karakter. Hasil penelitian menunjukkan bahwa terjadi peningkatan keterlaksanaan RPP dari siklus I sebesar 3,53 menjadi 3,82, kategori pada siklus II. Ketuntasan hasil belajar siswa juga mengalami peningkatan dari siklus I sebesar $34 \%$ menjadi $82,75 \%$ pada siklus II. Begitu pula dengan pencapaian karakter kayuh baimbai yang mengalami peningkatan dari siklus I sebesar $68,5 \%$ menjadi $89,5 \%$. Diperoleh simpulan bahwa penerapan modul getaran gelombang dan bunyi bermuatan karakter di kelas VIII dikategorikan efektif dalam meningkatkan hasil belajar siswa.
\end{abstract}

Kata kunci: Modul pembelajaran, karakter, getaran, gelombang dan bunyi.

\section{Abstract}

This study aims to describe: the implementation of lesson plans, student learning outcomes and achievement of the Kayuh Baimbai paddling character. This research uses Classroom Action Research. This research was conducted in two cycles. The subjects of this study were 29 students of class VIII in one of the public junior high schools in Banjarmasin. Data were obtained through observation, learning outcomes tests and character assessment sheets. The results showed an increase in the implementation of lesson plans from the first cycle of 3.53 to 3.82, the category in the second cycle. The completeness of student learning outcomes also increased from the first cycle of $34 \%$ to $82.75 \%$ in the second cycle. Likewise, the achievement of the Kayuh Baimba character increased from the first cycle of $68.5 \%$ to $89.5 \%$. It was concluded that applying the sound and wave vibration module with character charge in class VIII was categorized as effective in improving student learning outcomes.

Keywords: Learning modules, characters, vibrations, waves and sounds.

Article History: Received: 29 October 2021

Accepted: 29 October 2021

How to cite: Misbah, Misbah, Wanda Aulia, Mustika Wati. (2021). Penerapan Modul Getaran Gelombang dan Bunyi Bermuatan Karakter untuk Meningkatkan Hasil Belajar Siswa, 2 (2). pp. 108-116. Retrieved from http://jurnal.fkip.unmul.ac.id/index.php/JLPF

Copyright (C) November 2021, Jurnal Literasi Pendidikan Fisika 
Penerapan Modul Getaran...

\section{PENDAHULUAN}

UU Republik Indonesia nomor 20 tahun 2003 pasal 1 ayat 1 menjelaskan bahwa pendidikan merupakan upaya dan rancangan agar dapat menciptakan proses pembelajaran dan suasana belajar agar siswa bersungguh-sungguh dalam mengembangkan kemampuan yang ada pada dirinya untuk mempunyai kekuatan spiritual keagamaan, akhlak mulia, kepribadian, kecerdasan, pengendalian diri, serta keterampilan yang dibutuhkan oleh dirinya sendiri, masyarakat, bangsa dan negara. Pendidikan juga merupakan suatu keperluan utama dalam kehidupan manusia, karena pendidikan memiliki tujuan yang sangat penting yaitu mampu menciptakan seseorang yang bermutu, cerdas serta berkarakter sehingga dapat memiliki pemikiran yang luas agar tercapainya cita-cita yang diharapkan. Kepribadian siswa yang cerdas dan berkarakter sangat diperlukan dalam proses pembelajaran untuk dapat mewujudkan tujuan pendidikan, agar dapat mewujudkan hal tersebut maka diperlukan proses pembelajaran yang bermuatan karakter.

Menurut Fitriani (2017) terbentuknya kepribadian siswa yang cerdas dan berkarakter ialah inti dari seluruh kegiatan pembelajaran. Adapun unsur yang mendukung dalam terbentuknya karakter yakni terpeliharanya nilai-nilai serta budaya yang berawal dari kearifan lokal setempat. Menanamkan nilainilai karakter bisa diajarkan sejak perserta didik duduk di bangku sekolah. Penanaman karakter siswa dapat dilakukan di sekolah, salah satunya melalui penerapan modul pembelajaran yang bermuatan karakter (Hartini et al., 2018; Mastuang et al., 2019; M Wati et al., 2020).

Berdasarkan hasil yang diperoleh pada ulangan harian di kelas VIII di salah satu SMPN di Kota Banjarmasin masih rendah, siswa yang mendapatkan nilai tidak tuntas yaitu mencapai $81,25 \%$ dari jumlah 32 orang siswa dengan kategori ketuntatasan minimum untuk mata peajaran IPA yakni $\geq 75$. Ada beberapa faktor yang mempengaruhi siswa pada saat proses pembelajaran yakni siswa mengalami kerumitan ketika pada saat memahami dari isi modul pembelajaran tersebut, materi atau pelajaran yang disampaikan di dalam modul pembelajaran masih sedikit atau kurang, sehinggga siswa harus mencari lagi sumber atau bahan pembelajaran lainn, serta modul pembelajaraan yang mereka gunakan di sekolah masih kurang memuat banyak contoh soal dan pada saat proses pembelajaraan kurangnya atau minimnya penanaman karakter pada siswa, serta perilaku siswa pada saat kegiatan belajar masih belum cukup baik. Hal ini disebabkan karena proses pembelajaran cenderung berpusat pada guru, sehingga siswa kurang aktif diskusi sesama siswa dalam suatu kelompok sehingga pada proses pembelajaran tidak ada terciptanya sikap kerja sama, membantu teman yang sedang mengalami kesulitan selama pembelajaran, tidak saling berbagi pengetahuan dan saling menghargai pendapat orang lain.

Menurut Zuriah et al., (2016), pembentukan perilaku bangsa sangat berpengaruh dalam memecahkan krisisnya karakter anak bangsa yang di hadapi pada saat ini, sebagai pondasi utama dalam mensukseskan Indonesia Emas 2025. Suparwoto (Anwar, 2015) menyatakan bahwa kesuksesan dalam proses pembelajaran sangat bergantung pada penggunaan sumber belajar yang digunakan selama proses pembelajaraan, konsep dapat ditangkap secara akurat, konkrit, realistis, dan utuh. Oleh sebab itu, di butuhkan pengembangan dan penerapan sumber belajar dalam bentuk bahan ajar agar dapat menunjang proses pembelajaran.

Modul merupakan salah satu penunjang dalam proses pembelajaran, karena dengan menggunakan modul mampu memudahkan siswa belajar mandiri di sekolah maupun di rumah tanpa bimbingan guru, sehingga dengan adanya modul bermuatan karakter diharapkan dapat menanamkan karakter pada siswa dan meningkatkan kualitas hasil belajar siswa. Hal ini sesuai dengan penelitian yang dilakukan oleh Sitorus (2020) menyatakan bahwa penggunaan modul terintegrasi nilai karakter efektif dalam meningkatkan tanggung jawab dan hasil belajar siswa. Menurut Satria \& Handhika (2015) modul bermuatan pendidikan karakter dapat memberikan efek yang signifikan bagi peningkatan minat belajar siswa. Menurut Indasari (2017) modul bermuatan pendidikan karakter yang telah dihasilkan dapat dinyatakan valid dari segi isi dan penyajiannya, praktis dalam penggunaannya dan efektif dalam 
Penerapan Modul Getaran...

meningkatakan respon, aktivitas dan hasil belajar siswa.

Berdasarkan uraian di atas maka peneliti melakukan penelitian sebagai tindakan perbaikan hasil belajar siswa kelas VIII di salah satu SMP Negeri di kota Banjarmasin pada mata pelajaran IPA dengan menerapan modul bermuatan karakter untuk meningkatkan hasil belajar siswa. Tujuan penelitian ini ialah meningkatkan hasil belajar fisika dan karakter siswa, serta mendeskripsikan keterlaksanaan RPP pembelajaran fisika.

\section{METODE}

Jenis penelitian ini merupakan penelitian tindakan kelas, dengan menggunakan model Kemmis and Mc Taggart (Kemmis \& McTaggart, 1988), bertujuan agar dapat mengatasi permasalahan dikelas VIII di salah satu SMP Negeri di kota Banjarmasin. Setiap siklus pembelajaran terdiri dari yakni: perencanaan, pelaksanaan (tinidakan), pengamatan (observasi), serta refleksi. Penelitian ini terdiri atas 2 siklus, dimana masing-masing siklus dilaksanakan dalam 2 kali pertemuan setiap siklus. Untuk tahap perencanaan maka peneliti menyusun rancangan meliputi materi ajar, RPP, lembar kerja siswa (LKS), tes hasil belajar (THB), lembar observasi keterlaksanaan RPP serta lembar observasi karakter kayuh baimbai. Tahap selanjutkan pelaksanaan (tindakan) melakukan implementasi atau tindakan di dalam kelas sesuai dengan prosedur pembelajaran yang telah disusun dalam rencana pembelajaran. Kemudian Pengamatan (observasi) yaitu melakukan tindakan kelas, yang dilakukan oleh guru atau observer (guru mitra dan teman sejawat). Untuk tahap akhir yaitu diadakan refleksi untuk mengkaji tindakan terhadap kegiatan belajar mengajar dengan menerapkan modul bermuatan karakter untuk meningkatkan hasil belajar dan karakter siswa, serta menganalisis keterlaksanaan RPP. Subjek penelitian adalah 29 siswa di kelas VIII yang terdiri dari 34 siswa dengan rentang umur berkisar 13 tahun sampai 14 tahun.

Adapun Teknik pengumpulan data yang digunakan yakni, tes, non tes dan dokumentasi. Untuk Teknik tes dilakukan setelah 2 kali pertemuan untuk satu siklus dalam bentuk ujian tertulis yaitu berupa soal-soal essay. Teknik non tes dilakukan dengan cara melakukan pengamatan untuk mengetahui keterlaksanaan RPP dan tingkat pencapaian karakter kayuh baimbai yang dilakukan oleh peneliti.

Teknik analisis data dilakukan dengan menghitung nilai rata-rata yang diperoleh dari setiap aspek yang diamati yaitu keterlaksanaan RPP, pencapaian karakter kayuh baimbai, dan hasil belajar siswa. Keterlaksanaan RPP dideskripsikan dalam kriteria menurut Ratumanan \& Theresia (2011), disajikan pada Tabel 1.

Tabel 1. Kriteria keterlaksanaan RPP

\begin{tabular}{ccc}
\hline No. & Kriteria & Kategori \\
\hline 1. & $1,00-1,99$ & Tidak baik \\
\hline 2. & $2,00-2,99$ & Kurang baik \\
\hline 1. & $3,00-3,49$ & Cukup baik \\
\hline 4. & $3,50-4,00$ & Baik \\
\hline
\end{tabular}

Pencapaian karakter kayuh baimbai dideskripsikan pada Tabel 2 berdasarkan kriteria Widoyoko (2016), sedangkan hasil belajar siswa dideskripsikan berdasarkan ketuntasan individu dan ketuntasan klasikal yang ditetapkan oleh sekolah.

Tabel 2. Kriteria Penilaian Pencapaian Karakter Siswa

\begin{tabular}{ccc}
\hline No. & Interval & Kategori \\
\hline 1 & $\mathrm{X}>3,25$ & Sangat Baik \\
\hline 2 & $2,5<\mathrm{X} \leq 3,25$ & Baik \\
\hline 3 & $1,75<\mathrm{X} \leq 2,5$ & Cukup \\
\hline 4 & $\mathrm{X} \leq 1,75$ & Kurang \\
\hline
\end{tabular}

Kriteria keberhasilannya ialah hasil belajar siswa mengalami peningkatan pada setiap pertemuannya, yang di dukung oleh: Keteralaksanaan RPP minimal berkriteria baik, dan hasil belajar

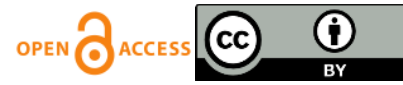


Penerapan Modul Getaran...

secara klasikal ketunatasannya minimal $75 \%$ serta kakarter siswa minimal berkriteria baik.

\section{HASIL DAN PEMBAHASAN}

HASIL

Penerapan modul bermuatan karakter dilakukan untuk meningkatkan hasil belajar siswa pada materi getaran gelombang dan bunyi dan karakteristik siswa kelas VIII. Modul yang diterapkan ini terdiri dari RPP, materi ajar, lembar kerja siswa (LKS), tes hasil belajar (THB), lembar observasi karakter kayuh baimbai dan lembar observasi keterlaksanaan RPP.

Uraian materi ajar diterapkan ke dalam 4 pertemuan, pertemuan 1 getaran, frekuensi dan priode, pertemuan 2 gelombang, panjang gelombang dan cepat rambat gelombang dan pemantulan gelombang, pertemuan 3 bunyi, infrasonik, audiosonik, ultrasonik, medium perambatan bunyi dan cepat rambat bunyi, pertemuan 4 nada, frekuensi pada senar dawai, resonansi dan pemantulan bunyi. Pada setiap pertemuan terdapat lembar kerja siswa (LKS) untuk membuat siswa dapat melakukan kegiatan baik secara individu maupun diskusi kelompok sesuai dengan model yang digunakan. LKS yang berisi kerja praktikum disertai adanya soal pemantapan di bagian akhir LKS. Tes hasil belajar siswa (THB) untuk mencek kembali pemahaman siswa berkaitan dengan materi pelajaran yang susah disampaikan tanpa melihat buku. Berikut tampilan modul yang diterapkan pada Gambar 1 (a) materi ajar dan 1 (b) lembar kerja siswa.
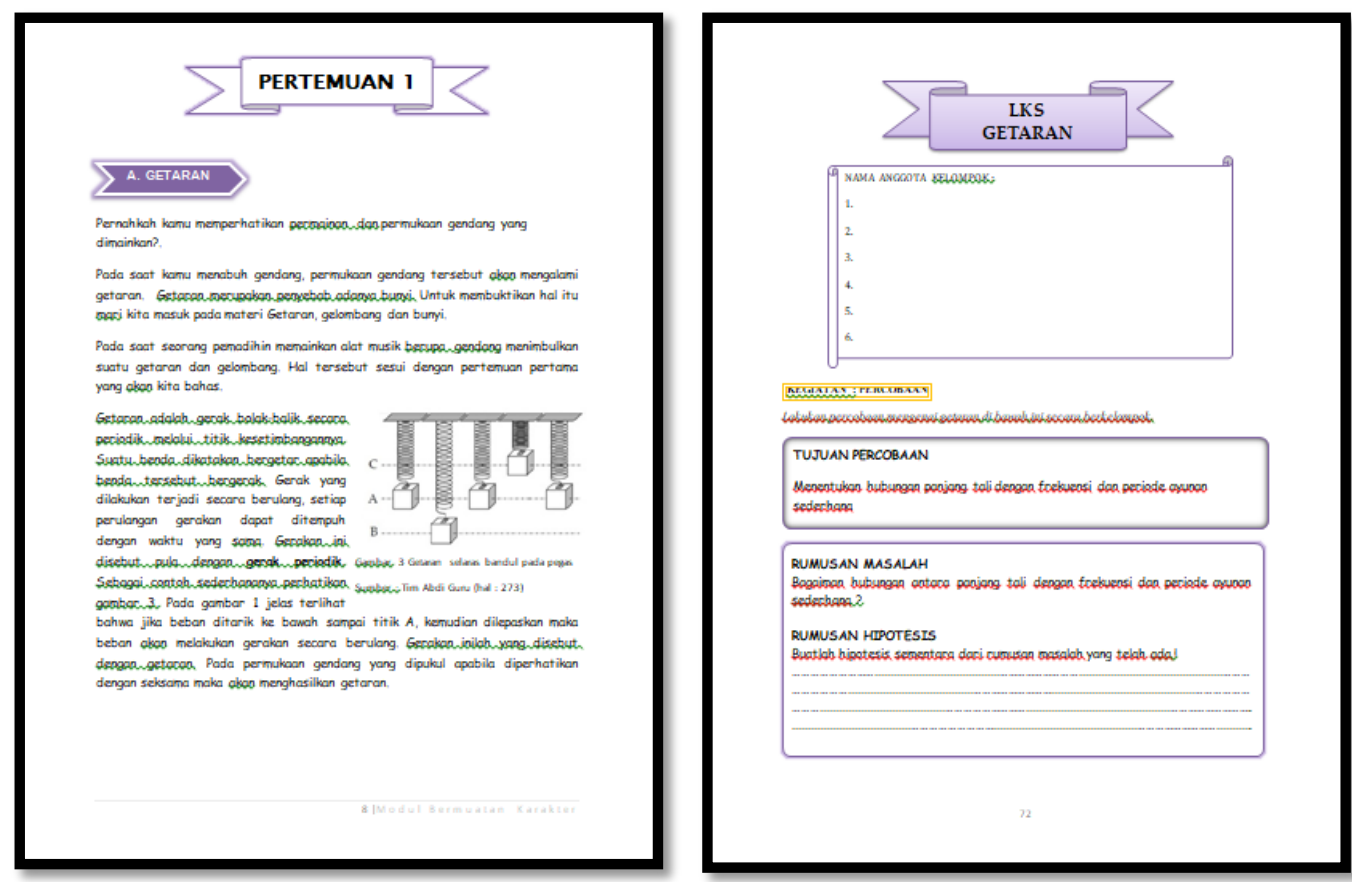

Gambar 1 (a). Tampilan materi ajar yang diterapkan dan 1(b) Lembar kerja siswa (LKS)

Berikut tampilan pojok karakter yang terdapat pada materi ajar yang digunakan disajikan pada Gambar 2.

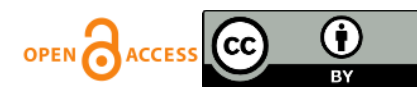


Penerapan Modul Getaran...
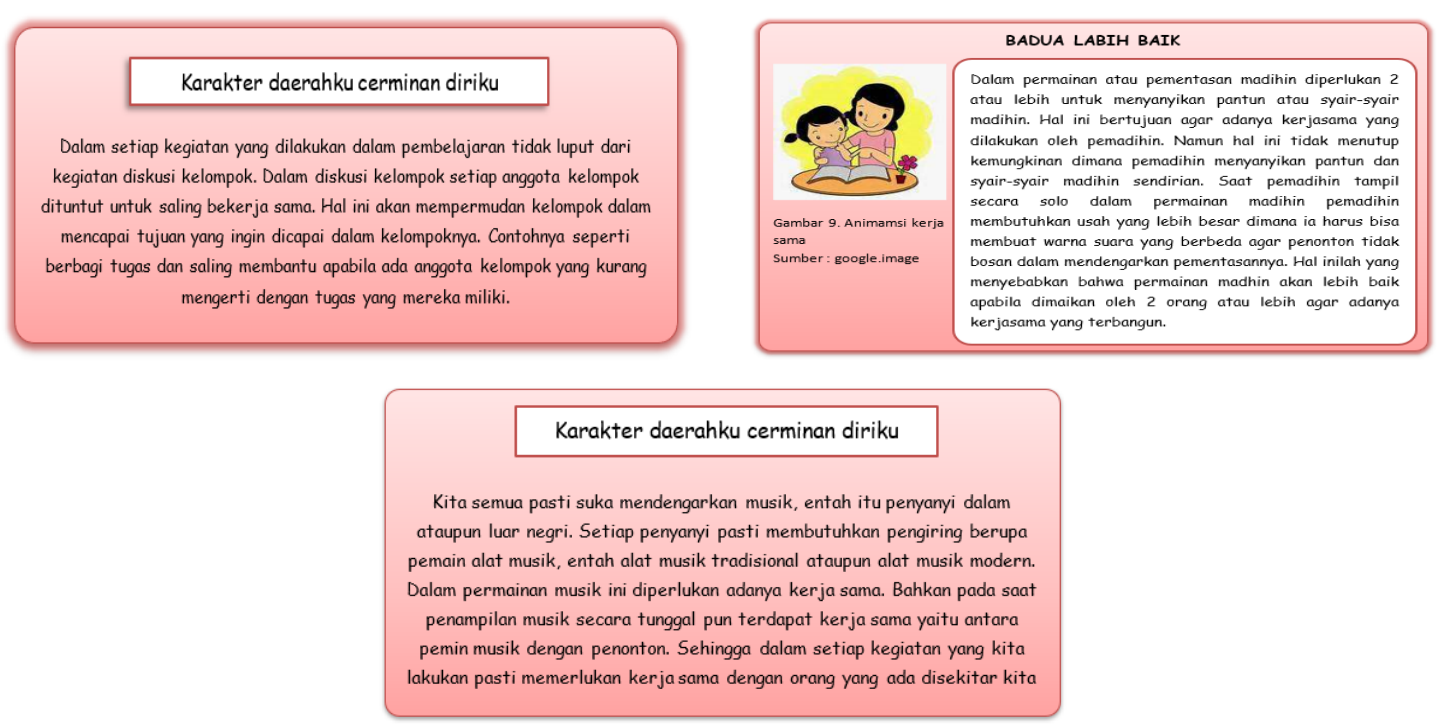

Gambar 2. Tampilan Pojok Karakter pada Materi Ajar

\section{Keterlaksanaan RPP}

Observasi pada keterlaksanaan RPP dengan menggunakan model pembelajaran kooperatif diamati oleh dua orang pengamat yang dilakukan pada setiap pertemuan dalam penelitian, skor rata-rata yang dihasilkan berkategori dengan sangat baik (4), baik (3), cukup baik (2), dan kurang baik (1). Berikut terlampir Keterlaksanaan RPP untuk siklus I \& siklus II dideskripsikan di dalam Tabel 3.

Tabel 3. Keterlaksanaan RPP

\begin{tabular}{|c|c|c|c|c|c|}
\hline & \multirow{2}{*}{ Fase } & \multicolumn{2}{|r|}{ Siklus I } & \multicolumn{2}{|r|}{ Siklus II } \\
\hline & & Nilai & Kategori & Nilai & Kategori \\
\hline \multicolumn{6}{|c|}{ Pendahuluan } \\
\hline Fase 1 & $\begin{array}{l}\text { Menyampaikan tujuan dan } \\
\text { motivasi siswa }\end{array}$ & 4,00 & Sangat Baik & 4,00 & Sangat Baik \\
\hline Fase 2 & Menyajikan informasi & 3,55 & Sangat Baik & 4,00 & Sangat Baik \\
\hline Fase 3 & $\begin{array}{l}\text { Mengorganisasikan siswa } \\
\text { ke dalam kelompok- } \\
\text { kelompok } \\
\text { Belajar }\end{array}$ & 2,60 & Baik & 3,60 & Sangat Baik \\
\hline Fase 4 & $\begin{array}{l}\text { Membimbing kelompok } \\
\text { kerja dan belajar }\end{array}$ & 3,55 & Sangat Baik & 3,80 & Sangat Baik \\
\hline Fase 5 & Evaluasi & 3,45 & Sangat Baik & 3,55 & Sangat Baik \\
\hline Fase 6 & Memberi Penghargaan & 4,00 & Sangat Baik & 4,00 & Sangat Baik \\
\hline Fase 7 & Penutup & 3,60 & Sangat Baik & 3,80 & Sangat Baik \\
\hline \multicolumn{2}{|c|}{ Rata-rata Keseluruhan } & 3,53 & Sangat Baik & 3,82 & Sangat Baik \\
\hline \multicolumn{2}{|c|}{ Reliabilitas (\%) } & 0,84 & Tinggi & 0,96 & Tinggi \\
\hline
\end{tabular}

\section{Karakter Kayuh Baimbai}

Aspek pencapaian pada karakter kayuh baimbai yang diamati oleh dua orang pengamat, dengan indikator kerjasama meraih tujuan, memperhatikan perasaan orang lain, memotivasi orang lain dan membantu teman. Pencapaian nilai karakter siswa didapatkan hasil menghitung skor rata-rata pencapaiannya pada setiap pertemuan siklus I dan siklus II di deskripsikan pada Tabel 4 . 
Penerapan Modul Getaran...

Tabel 4. Karakter Kayuh Baimbai

\begin{tabular}{cccccccc}
\hline Siklus I & Rata-rata & Persentase & Kategori & Siklus II & Rata-rata & Persentase & Kategori \\
\hline Pert 1 & 3,27 & $67,0 \%$ & Cukup & Pert 1 & 3,55 & 88,0 & Baik \\
\hline Pert 2 & 3,36 & $70,0 \%$ & Cukup & Pert 2 & 3,65 & 91,0 & Baik \\
\hline Jumlah & 3,31 & $68,5 \%$ & Cukup & Jumlah & 3,60 & 89,5 & Baik \\
\hline
\end{tabular}

\section{Hasil Belajar}

Adapun dalam Hasil belajar siswa diperoleh dari tes hasil belajar (THB) yang dilaksanakan setiap akhir siklus penelitian. Hasil belajar siswa siklus I dan II di deskripsikan pada Tabel 5.

Tabel 5. Hasil Belajar Siswa

\begin{tabular}{clcc}
\hline \multirow{2}{*}{ No } & \multicolumn{1}{c}{ Aspek Tinjauan } & \multicolumn{2}{c}{ Kuantitas } \\
\cline { 3 - 4 } & Jumlah siswa & Siklus I & Siklus II \\
\hline 1 & Jumlah siswa tuntas & 10 & 29 \\
\hline 2 & Jumlah siswa tidak tuntas & 19 & 24 \\
\hline 3 & Persentase tuntas individual & 63,86 & 5 \\
\hline 4 & Ketuntasan Klasikal & Tidak Tuntas & 77,96 \\
\hline & & & Tuntas \\
\hline
\end{tabular}

\section{PEMBAHASAN}

\section{Keterlaksanaan RPP}

Keterlaksanaan rencana pelaksanaan pembelajaran (RPP) berkriteria yakni sangat kurang, kurang, cukup, dan baik, serta sangat baik. Berdasarkan dari nilai rata-rata yang telah diperoleh dari penilaian dua orang observer yaitu kegiatan pembelajaran yang dilakukan telah seseuai dengan RPP. siklus I dihasilkan keterlakasaan RPP berkategori sangat baik dalam semua aspek penilaian memperoeh nilai rata-ratanya yaitu 3,53 berkriteria sangat baik, kemudian reliabilitasnya 0,84 berkategori tinggi serta memperoleh keterlaksanaan RPP sebesar 90\%. Meskipun keterlaksaanan RPP mencapai kriteria sangat baik namun masih ada beberapa tahapan dalam RPP yang kurang terlaksana dengan baik. Kurang terlaksananya beberapa tahapan ini disebabkan karena faktor waktu. Hal ini terjadi karena guru yang masih kurang menguasai kelas dalam mengelola waktu. Selain itu ada tahapan dalam kegiatan pembelajaran yang dilaksanakan waktunya terlalu lama terutama pada saat mengorganisasikan siswa ke dalam kelompok belajar terlalu memakan waktu lama. Serta guru tidak melakukan peragaan simulasi yang berkaitan dengan konsep getaran dan gelombang sehingga cukup memakai waktu yang cukup lama karena harus membimbing siswa setaip kelompoknya pada saat melaksanakan percobaan. Sehingga dapat kita simpulkan bahwa indikator keberhasilan keterlaksanaan RPP telah tercapai dengan berkriteria baik.

Semua aspek penilaian keterlaksanaan RPP siklus II menghasilkan perolehan yang sama dengan siklus I yakni skor rata rata menjadi 8,82 yang artinya juga mengalami peningkatan dengan kriteria sangat baik, reliabilitasnya sebesar 0,96 berkategori tinggi dan memperoleh keterlaksanaan RPP sebesar $95,75 \%$. Keterlaksanaan RPP secara keseluruhan pada siklus II terlaksana sangat baik dan meningkat serta langkah-langkah pembelajaran yang kurang optimal tidak sebanyak pada siklus I, meningkatnya dari data yang diperoleh keterlaksanaan RPP menunjukkann bahwa peneliti sudah bagus ketika daalam mengelola ruangan kelas meskipun masih ada beberapa bagian yang belum terlaksana dengan baik, dikarenakan faktor durasi yang sedikit. Karena dapat disimpulkan telah tercapailah sudah indikator keberhasilan dari siklus II.

Untuk keterlaksanaan RPP siklus I \& siklus II sudah memperoleh kategori sangat baik, oleh sebab itu dapat di simpulkan indikator pencapaian keberhasilan dengan menggunakan model pembelajaran kooperatif minimal berkategori baik. 
Penerapan Modul Getaran...

\section{Karakter Kayuh Baimbai}

Pencapaian karakter kayuh baimbai dilakukan oleh dua orang pengamat yang dinilai dengan menggunakan lembar observasi. Indikator kayuh baimbai yaitu kerjasama meraih tujuan, memperhatikan perasaan orang lain, memotivasi orang lain, dan membantu teman. Aspek yang diamati kerjasama dalam menyelesaikan tugas kelompok.

Pencapaian karakter siswa pada siklus I memperoleh nilai rata-rata 3,31 dengan persentase sebesar $68,5 \%$. Sedangkan untuk siklus II hasil yang diperoleh mengalami peningkatan yaitu rata-rata sebesar 3,6 dengan persentase sebesar $89,5 \%$.

Adapun indikator yang mengalami perubahan dalam setiap pembelajaran adalah saling bekerjasama saat mengisi lembar kerja dengan anggota kelompok, saling membantu teman apabila mengalami kesulitan selama pembelajaran, saling memberikan dukungan antar anggota kelompok dan bertoleransi atau saling menghargai pendapat orang lain selama pembelajaran berlangsung. Lembar pengamatan yang dinilai pada saat pembelajaran berlangsung, dan juga nilai dari lembar kerja yang semakin meningkat. Sedangkan indikator yang tidak tercapai adalah mengikuti peraturan selama pembelajaran, dalam awal proses pembelajaran siswa banyak yang tidak memperhatikan aturan pembelajaran karena usia siswa yang masih sangat muda sehingga cara berpikir siswa masih abstrak namun dapat berpikir secara logis dan rasional.

Berdasarkan hasil pengamatan bahwa modul yang diterapkan mampu mencapai karakter kayuh baimbai. Hal ini disebabkan karena di dalam modul tersebut terdapat pojok karakter, sehingga terwujudnya indikator kerjasama. Pojok karakter ini berisi kalimat motivasi serta deskripsi penerapan dari indikator Kerjasama, seperti yang tampak pada Gambar 2. Berdasarkan pengertian dari kayuh baimbai maka karaktereristik yang diharapkan akan tercapai adalah karakter kerjasama. Sesuai dengan penelitian Tama (2019) tentang pengembangan modul fisika berbasis nilai-nilai karakter islami pada materi gelombang bunyi yang menunjukkan modul dapat menarik bagi siswa untuk membaca dan memahami modul. Oktaviana, Hartini, \& Misbah (2017) menunjukkan bahwa penggunaan modul berintegrasi nilai karakter di dalamnya dapat meningkatkan hasil belajar siswa. Hasil penelitian Noorhidayati, Hartini, \& Suyidno (2014) menunjukkan penerapan model pembelajaran kooperatif berbais karakter efektif dan dapat meningkatkan hasil belajar. Hasil penelitian Hasani,Hartini, \& An'nur (2019) menunjukkan bahwa penerapan modul fisika bermuatan kearifan lokal dapat meningkatkan keterampilan proses sains dan karakter kayuh baimbai siswa. Erinda, Indriwati, \& Sulasmi (2019) menunjukkan yaitu modul nermuatan karakter layak dan efektif untuk meningkatkan hasil belajar dan keterampilan proses.

\section{Hasil Belajar}

Ketuntansan secara klasikal didapatkan dari tes THB yang telah dilakukan pada setiap akhir siklus, dari hasil tersebut kemudian diukur dengan mengguanakan THB pada setiap akhir pembelajaran dinyatakan tuntas dan tidak tuntas dan dinyatakan dengan presentase ketuntasan klasikal. Hasil belajar siswa ketunatasan klasikal setiap siklusnya mengalami peningkatan. Siklus I hanya 10 orang siswa yang memperoleh nilai secara tuntas dan terdapat 19 orang siswa yang tidak tuntas secara individu. Maka siklus ini di kategorikan tidak tuntas dikarenakan belum berhasil memperoleh $75 \%$. Banyaknya siswa yang tidak tuntas sebagian besar disebabkan karena siswa tidak berhasil mengerjakan soal nomor 1 dan 3. Hal ini disebabkan siswa kurang menguasai materi pelajaran dan kurang teliti dalam menentukan besaran-besaran yang diketahui maupun yang ditanya serta siswa kurang menguasai rumus-rumus yang digunakan. Dari data tersebut, maka dapat dikatakan bahwa indikator pencapaian keberhasilan penelitisan pada ketunttasan hasil belajar secara klasikal minimal $70 \%$ tidak tercapai.

Ketuntasan klasikal siklus II memperoleh nilainya sebesar $82,75 \%$, karena terdapat 24 orang siswa yang berhasil mendapatkan nilai ketuntasan secara individu dan hanya 5 siswa yang tidak mendapatkan nilai ketuntasan secara individu, maka dari hasil tersebut dapat kita lihat bahwa ketuntasan klasikalnya telah mengalami peningkatan pada siklus I ke siklus II dan siklus II ketuntasan 
Penerapan Modul Getaran...

klasikalnya berkategori tuntas, karena sudah mencapai indiaktor keberhasilan maka tidak dilanjutkan pada siklus berikutnya.

Berdasarkan data pada Tabel 5 maka dapat dilihat ketuntasan klasikalnya pada siklus I ke siklus II mengalami peningkatan yang sangat baik, walaupun masih ada beberapa siswa yang belum tuntas. Oleh karena itu maka dengan adanya menerapkan modul bermuatan karakter kayauh baimbai dapat memudahkan siswa untuk belajar secara mandiri sehingga mampu meningkatkan hasil belajar pserta didik. Meningkatnya nilai tersebut terjadi karena siswa berperan secara langsung dan secara aktif pada proses pembelajaran dengan mengamati objek dan melihat secara jelas serta siswa juga dapat memahami konsep dari getaran gelombang dan bunyi. Dengan demikian dapat disimpulkan bahwa dengan menerapkan modul bermuatan karakter dapat meningkatkan hasil belajar siswa disetiap siklusnya.

Hal ini sejalan dengan penelitian Noperi (2014) yang menyatakan pencapaian hasil belajar siswa ketika menggunakan modul IPA bermuatan pendidikan karakter mengalami peningkatan. Saputri, Darvina, Putra, \& Sari (2019) mengatakan bahwa pengaruh penerapan bahan ajar bermuatan karakter terhadap pencapaian kompetensi siswa nilai rata-rata kompetensi pengetahuan kelas eksperimen lebih tinggi dari nilai rata-rata kompetensi pengetahuan kelas. Wati, Hartini, Misbah, \& Resy (2017) hasil penelitiannya menunjukkan modul fisika berintegrasi kearifan lokal Hulu Sungai Selatan layak untuk digunakan dalam proses pembelajaran.

\section{PENUTUP}

Berdasarkan dari hasil yang diperoleh serta pembahasan penelitian yang telah dilakukan, maka dapat disimpulkan bahwa terdapat peningkatan hasil belajar siswa setelah siswa mengikuti pembelajaran menggunakan modul getaran, gelombang dan bunyi bermuatan karakter di kelas VIII pada tingkat sekolah menegah pertama.

\section{DAFTAR PUSTAKA}

Anwar, N. (2015). Pengembangan Modul IPA. UIN Sunan Kalijaga.

Erinda, L., Indriwati, S. E., \& Sulasmi, E. S. (2019). Pengembangan Modul Keanekaragaman Tumbuhan Home Science Process Skill Berbasis Inkuiri Terbimbing Bermuatan Karakter Untuk Meningkatkan Hasil Belajar Dan Keterampilan Proses di MAN 1 Malang. Jurnal Pendidikan Biologi, 9(2), 64-70.

Hartini, S., Firdausi, S., Misbah, \& Sulaeman, N. F. (2018). The development of physics teaching materials based on local wisdom to train Saraba Kawa characters. Jurnal Pendidikan IPA Indonesia, 7(2), 130-137. https://doi.org/10.15294/jpii.v7i2.14249

Hasani, N. L., Hartini, S., \& An'Nur, S. (2019). Meningkatkan keterampilan proses sains dan karakter kayuh baimbai melalui module fisika bermuatan kearifan lokal. Jurnal IImiah Pendidikan Fisika, 3(2), 65-76.

Indasari, L. (2017). Pengembangan Modul Pembelajaran Biologi Bermuatan Pendidikan Karakter untuk Siswa Kelas XI IPA SMAN 3 Kerinci.

Kemmis, S., \& McTaggart, C. (1988). The action research planner. Deakin University Press.

Mastuang, M., Misbah, M., Yahya, A., \& Mahtari, S. (2019). Developing the physics module containing Quranic verses to train the local wisdom character. Journal of Physics: IOP Conference Series, 1171, 01201-1. https://doi.org/10.1088/1742-6596/1171/1/012018

Noorhidayati, N., Hartini, S., \& Suyidno, S. (2014). Meningkatkan hasil belajar siswa melalui penerapan model pembelajaran kooperatif tipe team games tournament (TGT) berbasis karakter. Berkala IImiah Pendidikan Fisika, 2(1), 22-30.

Noperi, H. (2014). Pengembangan Modul Ilustratif Pembelajaran IPA SMP Berbasis Inkuiri Terbimbing Bermuatan Pendidikan Karakter.

Oktaviana, D., Hartini, S., \& Misbah, M. (2017). Pengembangan modul fisika berintegrasi kearifan lokal membuat minyak lala untuk melatih karakter sanggam. Berkala Ilmiah Pendidikan Fisika, 5(3), 272. https://doi.org/10.20527/bipf.v5i3.3894

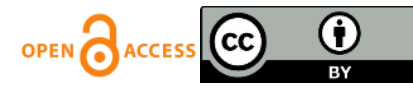


Penerapan Modul Getaran...

Ratumanan, T. G., \& Theresia, L. (2011). Evaluasi Hasil Belajar yang Relevan dengan Kurikulum Berbasis Kompetensi. Unesa University Press.

Saputri, Y. E., Darvina, Y., Putra, A., \& Sari, S. Y. (2019). Pengaruh Penerapan Bahan Ajar Interaktif Bermuatan Karakter Menggunakan Model Pembelajaran Discovery Learning Pada Materi Fluida Terhadap Pencapaian Kompetensi Siswa Kelas XI SMAN 7 Solok Selatan. Pillar Of Physics Education, 12(4).

Satria, H., \& Handhika, J. (2015). Pembelajaran fisika menggunakan modul berbasis scientific approach bermuatan pendidikan karakter pada materi termodinamika. In Seminar Nasional Fisika dan Pendidikan Fisika Ke-4 2015. Sebelas Maret University.

Sitorus, D. S. (2020). Meningkatkan Tanggung Jawab Dan Hasil Belajar Siswa Melalui Penggunaan EModule Akuntansi Terintegrasi Nilai Karakter. Jurnal Ekonomi Pendidikan Dan Kewirausahaan, $8(1)$.

Tama, O. N. (2019). Pengembangan Modul Fisika Berbasis Nilai-Nilai Karakter Islami Pada Materi Gelombang Bunyi.

Wati, M, Putri, M. R., Misbah, M., Hartini, S., Mahtari, S., \& ... (2020). The development of physics modules based on madihin culture to train kayuh baimbai character. Journal of Physics .... https://doi.org/10.1088/1742-6596/1422/1/012008

Wati, Mustika, Hartini, S., Misbah, M., \& Resy, R. (2017). Pengembangan Modul Fisika Berintegrasi Kearifan Lokal Hulu Sungai Selatan. Jurnal Inovasi Dan Pembelajaran Fisika, 4(2), 157-162.

Widoyoko, E. P. (2016). Evaluasi program pembelajaran. In Evaluasi Program Pembelajaran. Pustaka Pelajar.

Zuriah, N., Widodo, R., \& Sunaryo, H. (2016). Model Pendidikan Karakter Berbasis Nilai Kearifan Lokal dan Civic Virtue Sebuah Rekayasa Sosial. 